報文

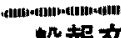

一般報文

(昭和 51 年 9 月 24 日受理)

$$
\begin{aligned}
& \text { ポリエチレンテレフタレートの } \\
& \text { 有機溶骫中における結晶化 }
\end{aligned}
$$

\author{
福井大学工学部渡辺孝寛 ${ }^{*}$.三好政和
}

高橋利禎 - 过本石雄

\title{
CRYSTALLIZATION OF POLY(ETHYLENE TEREPHTHALATE)
}

IN ORGANIC SOLVENT By Takahiro Watanabe, Masakazu Miyoshi. Toshisada Takahashi,
and Ishio Tsuimoto

(Faculty of Engineering, Fukui University, Fukui City, Fukui Prefecture, Japan)

\begin{abstract}
The amorphous and undrawn poly(ethylene terephthalate) (PET) was treated with several kinds of organic solvents and silicon oil at temperatures of $-10^{\circ} \mathrm{C}$ to $200^{\circ} \mathrm{C}$, and the fine structure was investigated by means of X-ray diffraction (wide-angle and small-angle) and density gradient tube. The degree of swelling of PET treated with benzyl alcohol, benzene, tetrachloroethylene, and chloroform increased with the rise of treatment temperature. On the other hand, the degree of swelling of PET treated with dimethyl formamide (DMF), dimethyl acetoamide, and nitrobenzene at $-10 \mathrm{C}-75 \mathrm{C}$ increased with a lowering of temperature. This unusual swelling behavior of PET was discussed on the basis of the interaction between PET and organic solvent. The degree of crystallinity of PET treated with organic solvent increased with the rise of temperature in every case. The crystallization was almost completed up to about $10^{\circ} \mathrm{C}$ in DMF and benzene. Acceleration of the crystallization in organic solvent may be attributed to the fact that the glass transition temperature of PET is lowered in organic solvent. The dominant selective uniplanar orientation of (100) plane was found for the PET which was treated with DMF in lower temperature.
\end{abstract}

(Received September 24, 1976)

\section{1. 緒言}

最近，多様化する加工技術や公害問題などに対応する

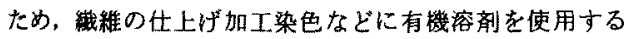
機会がふえている。したがって，有機容郕が高分子の構 造と物性に与える影響について明らかにすることは必要と 考えられる。この分野に関しては将賀等 ${ }^{1)}$, 万木等 ${ }^{2}$ の報 告がある。海外では H. G. Zackmann"), W. R. Moore"，J.

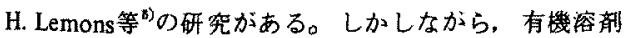
中で結晶化したポリエチレンテレフタレート（以下PET）

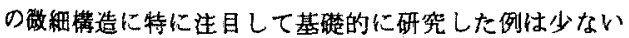
ようである。 ※ーレン怢式会社
本研究は非晶性 PETを各種有機容郕中でー10〜150 ${ }^{\circ}$ Cに扔いて処理した時の構造変化を明らかにするととも に，PETと有機溶剤との相互作用を検討しょうという 目的で行なわれたものである。PETの膨溜度の温度体 存性を測定するとともに，主に溶剤除去後のP PT の結 晶化度，X線小角散乱能などを測定した。その結果シメ チルホルムアミド(DMF)，ジチルアセトアミト (DMA), =トロベンゼン中において, $75^{\circ} \mathrm{C}$ 以下の低温 において处理したPETの膨潤挙動やX 線小解散乱能な

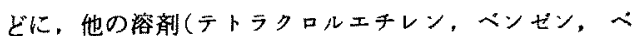
ソシルアルコール)中に扔いて処理したPETのそれとは 異なった特異な現象のあること，DMF中で低温におい て処理すると坧延などの機械的力を加えなくても(100) 
面がフイルム面に平行に配向することなどが明らかにさ れたので報告する。

\section{2. 実験方法}

\section{（1）試料作製}

末延伸の非晶性PETフィルム(東レ製，密度 $1.345 \mathrm{~g} /$ $\mathrm{cm}^{8}$ ，愿さ $\left.200 \mu\right)$ を原試料とした。フイルム注無配向品 であり複風折を測定したがほとんど認められなかった。 原試料をペンゼン，ニトロベンゼソ，DMF，DMA，ク ロロホルム，アセトニトリル、ベッシルアルコール，テ トラクロルエチレン、シクロへキサンなどの有機溶刱中

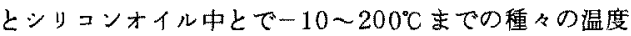

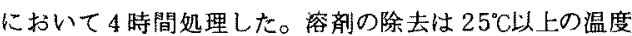
で処理した陚料については室温に扮いて，また $25^{\circ} \mathrm{C}$ 以 下の温度で処理した試料については，処理温度と同じ温 度において 48 時間エチルェーテルに漫漬し，溶剤とエ チルメーテルを置换後 200 時間以上减王乾燥することに 上り行なった。

\section{(2) 膨潤度の測定}

溶剂処理前の重量と溶剂処理を行ない溶剂中から取り 出した直後の重量(試料表面についている余分な溶剂は沪 紙で吸い取った）を測定し，次式でモル膨潤度を算出した。

$$
\frac{\left(m_{p+s}-m_{p}\right) / M_{s}}{\left(m_{p+s}-m_{p}\right) / M_{s}+m_{p} / M_{p}} \times 100
$$

ただし $m_{p}$ : 溶剂処理前の試料の重量， $m_{p+s}$ : 膨潤中の 試料の重量, $M_{8}$ : 溶剤の分子量, $M_{p}:$ PETの靕造単位 の分子量。

\section{(3) 密度測定}

四塩化炭素ーnヘプタンを用いて調整した密度勾配管 を用い，20足に执いてPETの密度を测定した。密度勾 配管に入れてから0〜12 時間の間の密度変化を評価した。 ここでは初期の比較的大きい密度変化の特期を経た後で ある 1 時間後の密度の値 $\rho_{p}$ より結晶化度 $X_{c r}$ を次式によ り算出した。

$$
\frac{1}{\rho_{p}}=\frac{X_{c r}}{\rho_{c}}+\frac{1-X_{c r}}{\rho_{a}}
$$

ここで結晶領域と非晶領域の密度はそれぞれ $\rho_{c}=$ $1.455 \mathrm{~g} / \mathrm{cm}^{8}, \rho_{a}=1.335 \mathrm{~g} / \mathrm{cm}^{3}$ とした して求めた結晶化度は面配向性のほとんどない試料につ いてX線回折法により求めた結晶化度にほぼ対応してい ることを別に確かめた。ボイドが形成されている陚料も あるので 1 時間後の密度が正しい結晶化度を与えるとい う保証はないが，この測定值を結晶化過程の定性的な娭 討のために用いることはさしつかえないと考えられる。 （4）広角X線回折 理学電機製 X 線回折装埧を使用した。 $\mathrm{Cu}$ 対隐極を用
いNi簿で沪過して単色化した点焦点 $\mathrm{CuK}_{\alpha}$ 線を用い広 角 X線回折图を得た。X線発生条件は $35 \mathrm{kV}, 15 \mathrm{~mA}$ ある。

（5）X線小角散乱

理学電機製 D-14 型X線小角散乱装置女使用 L Ni 簿 で汇過した線焦点 $\mathrm{CuK}_{\alpha}$ 線を用いた。第 1 スリット0.3 $\mathrm{mm}$ ，第 2 スリット $0.2 \mathrm{~mm}$, 散乱スリット $0.3 \mathrm{~mm}$, 力 ウンタースリット $0.1 \mathrm{~mm}$ とした。小角散乱強度の自記 記録は時定数 1 秒，走查速度 4 分 (角度)/分(時間)で0 度から 2 度 30 分の色度籍聿内で行なった。涀定した散乱 強度曲線は P. H. Hermans らの方法行従って空気散乱の 補正、試料の密度の相違による補正等について行なった。 なお 1 回の測定中の1次X線の強度変動は士0.5\%であ ることは別に確かめた。測定ごとに 1 次X線の最高強度 をチェックし同一強度で測定が行なわれるようにした。

\section{3. 結果と考察}

\section{(1) 腿潤度}

PETはほぼ非極性の高分子であるが，主鎖中にベンゼ ン環とエステル結合中のカルボニル基を持って㧍りここ れが溶剮との相互作用に関与してくると考えら扎るこ の実験では、アルカリ性(電子供与性)の溶都としてベン ゼン、ニトロベンゼン, DMF, DMAを, 酸性(電子受 容性〉の溶戍としてクロロホルム、フセトニトリ心：く ンジルフルコールを用いた。るの他テトラクロルェチレ ン：シクローキサンを使用した(溶剤の分類はLemons ${ }^{\text {5) }}$ によるもの)。

図1は各溶剤中で熱処理したPETのモル膨潤度を処 理温度に対してプロットしたものである。また，図2 は 密度より評值した結晶化度をPETの処理温度に対して プロットしたものである。

ところでPETを溶剂に浸漬すると膨潤が起こるが， それに引きつづいて結晶化が起こるので，その考察は性 意を要寸る。PETのある部分に扔ける結晶化は溶郕が その部分に浸入してから起こるのであるから，膨潤一結 晶化現象を第 1 段階(PETの溶剂による膨閏)，第 2 段

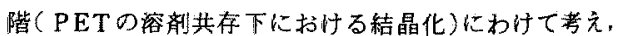
全温度範囲にわたる獥潤挙動を単純化して考察すること は可能であ万う。しかし実際には結晶化の影響のため， 膨潤度は結晶化の起こらない場合よりも低くなっている というような事，また拡散速度の遅い溶偊中では上記の 結晶化の影響を受けやすくなるといらような事を配感す る必要がある。

図 $1 の$ (膨潤度一温度)曲線は，明らかに 2 種類に分離 することができる。第1のダルーブの溶郕，ベジルア ルコール、ベンゼン，テトラクロルエキレン，ク口ロ本 


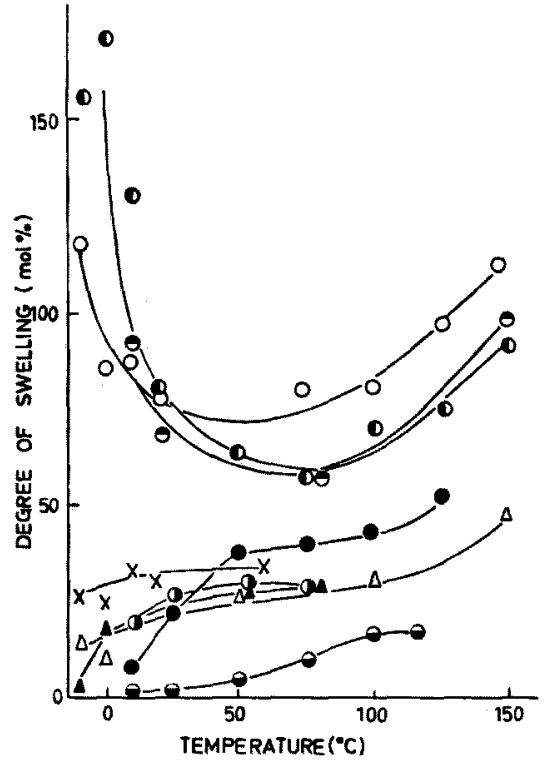

Fig. 1 Degree of swelling (mole \%) of PET treated with several kinds of organic solvents. Amorphous and undrawn PET was treated with organic solvent for 4 hours.

O-O PET treated with dimethyl formamide.

- PET treated with benzyl alcohol.

-O PET treated with benzene.

$-\odot$ PET treated with tetrachloroethylene.

- - PET treated with dimethyl acetoamide.

$-\rightarrow$ PET treated with nitrobenzene.

$x-x$ PET treated with chloroform.

$\triangle-\triangle$ PET treated with cyclohexane.

$\Delta-\Delta$ PET treated with acetonitrile.

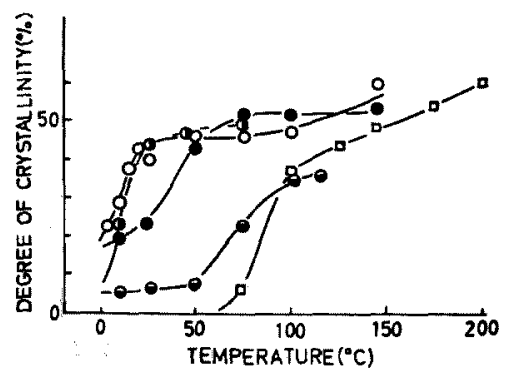

Fig. 2 Degree of crystallinity of PET treated with organic solvent and silicone oil for 4 hours at various temperatures.

O-O PET treated with dimethyl formamide.

- PET treated with benzyl alcohol.

- -0 PET treated with benzene.

- - PET treated with tetrachloroethylene.

$\square-\square$ PET treated with silicone oil.
ルム、シクロへキサン, アセトニトリル中に拟ては, PETの膨潤度は高温になるほど高くなり，S字型の曲 線が得られる。一方，第 2 グルーブの溶偊，DMF，

DMA，ニトロベソゼン中に招いては $50^{\circ} \mathrm{C}$ 以下で低涅に なるほど膨潤度が高く(膨潤度一温度)曲線には 50７0 ○に極小がある。

第1のグルプの溶戍についてであるが，クロロホル ムの場合はー $10^{\circ} \mathrm{C}$ にってもかなり膨潤度が高い。これ はPETのエステル基とクロロホルムの間に $-0 \mathrm{O}=0$ --H-C-Clのよらな相互作用が存在して拉り，これが低 Cl

温においても膨潤度が高くなることに奇与していると考 えられる。このグループの溶浏の中で,・トラクロルエチ レンとクロロホルムの凝集エネルギ一密度はそれぞれ9.3

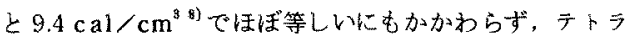
クロルェチレンの(膨潤度一温度)曲線はより高温側に移 行しており膨潤度も低い。これはテトラクロルェチレン の分子の化学構造より上記のク口ロルムの場合の上う な相互作用が期待されないこと，またその分子の大きさ が化学構造より考えてもわかるように大きい(テトラク ロルエチレンの広角X線回折強度曲線におけるハローの 㥛大の散乱角蛙 $2 \theta=11^{\circ}$ 付近であり，PETへの非晶 八ロ一のそれより低角側にある $\left.{ }^{9}\right)$ た PET内人の抬散 速度が荤くなり，膨潤に引き続いておこる結晶化の影響 を受けやすくなるなどのためPET内への吸収量が全体 として㧕制されると考えられる。

第 2 の゙ループの溶㓮中では上記のように，例えば DMFの場合 $-10 \sim 50^{\circ} \mathrm{C}$ 範果内で低温になるほど膨潤

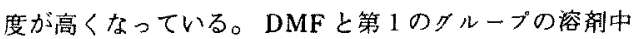
のペンゼンとペンジルアルコールの結晶化举動は次項で 明らかになるように(图2)よく類似している。それにも かかわらず，例充ば結晶化度が20\%より30\%に増大す る温度域でのPETの膨潤度はDMF中では低下してい るのに, ベンゼン, ヘンンジアルコール中では增大して

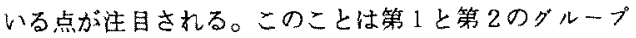
の溶剂とではPETとの相互作用に基本的に相違した点 のあることを示唆していると考えられる。低温になるほ ど膨潤度が高くなる現象注，ナイロンーフェノール水溶 浓 ${ }^{10)}$ の上5な極性高分子と極性溶剤との系において見出 されており，高分子と溶郕とが水素結合などの強い相互 作用を持つと考えられる系において認められる愣象であ る。本実呀の場合には結晶化が膨潤とともに進行するの で単純には报えないにしても，第2のグループの溶郕と PETの間には低温に抒いても何らかの強い相互作用が 存在していると考えないと，上記の膨潤挙動は説明でき ないようである。このことはいろいろの温度で処理した 
PETの小角散乱能の項にも関連してくる。第 1 のグル 一プのクロロホルムはむしろ第1と第 2 の゙ループの中 闃的存在といえよう。

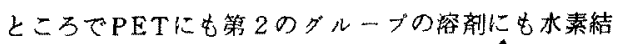
合を作るような水菜原子は含まれていない。じがって， $\mathrm{PET}$ とこれらの有機溶㓝との間にどのような特別な相 互作用が存在しているのかは現在のところ確認していな

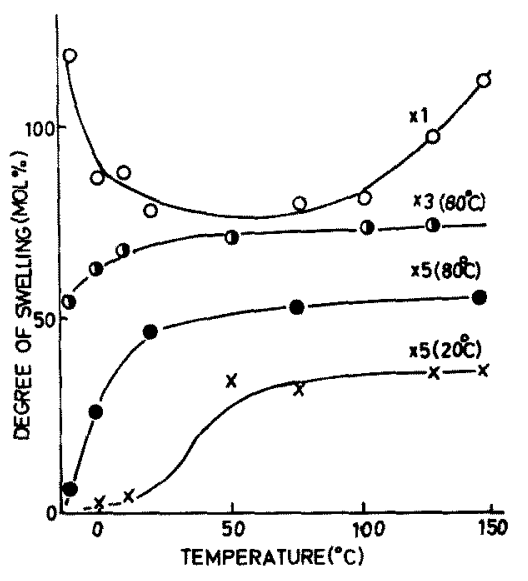

Fig. 3 Degree of swelling of drawn and undrawn PET treated with dimethyl formamide. PET drawn at $20^{\circ} \mathrm{C}$ and $80^{\circ} \mathrm{C}$ (draw ratio: 3 and 5 ) was treated for 4 hours.

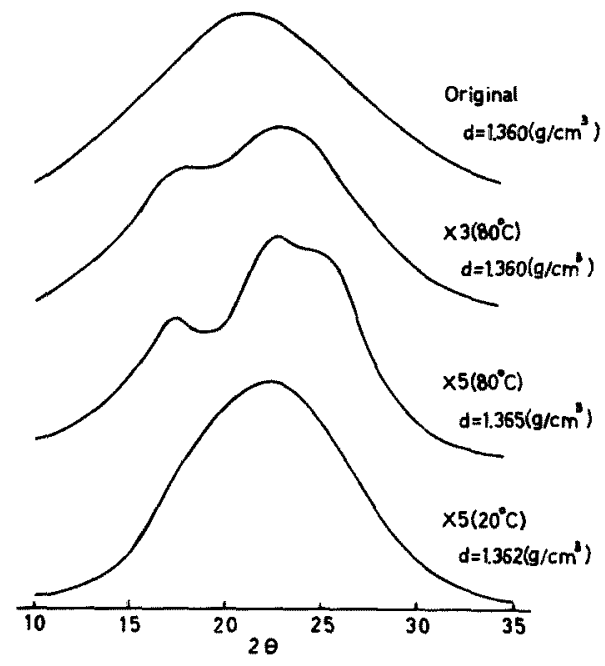

Fig. 4 Wide angle X-ray diffraction curves of equatorial scanning for PET.
い。PETのエステル結合中のカルボニル基と DMF， DMAのカルボニル基, ニトロベンゼンのニトロ基の双 極子閶の相互作用，PET中の $\pi$ 電子と溶剂の双極子間 の相互作用などが寄与していると考えられる。

このような PETと溶剤との相互作用はPETの分子 鎖の凝集状態に強く依存する。四 3 は延伸試料のDMF中 に拉りる(膨潤度一温度)曲線である。各試料の分子鎖凝 集状態は広角 X線回折強度曲線，熱分析などにより蛤討 した。図44图3の実験に使用したPETの広角X線回 折強度曲線(赤道上)である。部分的に結晶化するか，ま た牥分子間距離が近くなった試料(広角X線回折強度曲 線に执ける八ローの極大位䈯が広角側にシフトしている） については，DMF中における低温に拈ける膨潤度の增 大は誌められなくなる。この点，延伸熱処理したナ゙ロ ンのフェノール水溶夜中に括ける膨潤举動 ${ }^{10)}$ が图 1 と同様 であるのとは巽なっている。すなわち，PET-DMF系 ではその相互作用はいったん形成されたPET 分子鎖閒 の結合を破壊してしまうほど強いものではないと考えら れる。

(2) 結晶化度

（1）で述べた溶剤のなかで以下の実験ではDMF，よ ンゼン、ベンシルアルコール, テトラクロルエチレンの み用いた。面配向のほとんど認められない7陚料の P ET については膨潤中と㛺燥後の試料について結晶化度をX 線回折法て測定した(P.H. Hermans の方法") 与を美引いた)。その結果, 膨潤試料の結晶化度は競燥 試料の70〜80\%に達していることがわかった。例えば， テトラクロルェチレン中 $75^{\circ} \mathrm{C}$ 処理したPETの膨潤中お よび乾燥後の結晶化度は，それぞれ $27 \%$ と $33 \%$ あっ た。また，ベンゼン中 $75^{\circ} \mathrm{C} て ゙$ 処理したPETについては， それぞれ28\%と44\%であった。したがって結晶化の多 くの部分は膨潤過程で起こっていることは明らかである。 ここでは乾嬠試料の結晶化度を処理温度に対してプロッ

トした図 2 につて考察する。

溶剤中で処理した試料の結晶化度が急激が增加する温 度はDMF，ベンゼン中では $0^{\circ} \mathrm{C}$ 付近，ペンジアルュー ル中では $40^{\circ} \mathrm{C}$ 付近，そしてテトラクロルエチレン中では $70^{\circ} \mathrm{C}$ 付近にあり，いずれもシリコンオイル中での熱処

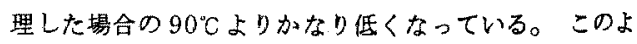
うに，結晶化開始温度が低下したのはPET中に唚入し

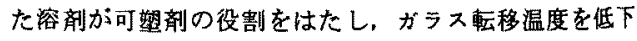
させ，その結果として結唱化のためのセグメント運動の 始まる温度が低下したためと考えられる。

\section{(3) $\mathrm{X}$ 線小角散乱能}

溶剤中で結晶化したPETの端細棈造についてさらに 検討するため，X線小角散乱強度分布曲楾からX線小角 
散乱能(以下散乱能と略称) を求め, 処理温度に対してブ ロットしたのが図 5 である。ただし, 綎軸の散乱能は測 定試料中最大の散乱能を示したDMF 中 $145^{\circ} \mathrm{C}$ 処理試料 の散乱能を 1 として相対的に表わした。

溶剤処理した試料の散乱能は DMF $75^{\circ} \mathrm{C}$ 以下で処理し た試料を除いて処理温度が上昇するとともに増大してい る。特にDMFとペンジルアルコール中の熱処理試料は $75^{\circ} \mathrm{C}$ 付近から処理温度上昇とともに急速に散乱能が增 大している。これらの処理試料が結晶と非結晶の 2 相の みから構成されているとすると, 散乱能は同一結晶化度 であれば同一散乱能を示してよい。しかし, 図 6 に示し た結晶化度と散乱能の関係から明白なように, 同一結晶 化度であっても容剤の種類によりその散乱能は大きく相 違してくる。一般に溶剤処理試料の散乱能は, シリコン オイル中の熱処理試料のそれにくらべて高い。これらの ことは密度の低いミクロボイドが溶剤処理中に試料内に 形成されるためであると考えられる。図 7 にはDMF 中 の $125^{\circ} \mathrm{C}$ 処理試料の $\mathrm{X}$ 線小角散乱図を示す。この図にお いて中心部分の円形状の散漫な散乱は球形状のボイドが 試料中に形成されたことを示唆している。

DMF 中で処理したPETの散乱能は, シリコンオイル 中で処理した試料に比較して散乱能がかなり高く, 図 5 の散乱能にはボイドの存在が支配的に寄与していると考 えられる。一方, DMF 中における膨潤度の温度依存性 の曲線には $75^{\circ} \mathrm{C}$ 付近に極小値があることについてはす で述べた。DMF 中熱処理したPETについては $10^{\circ} \mathrm{C}$ 以上では膨潤度と散乱能の温度依存性を示す曲線( 図 1 と図5)がほぼ対応しており,膨潤度が高くなるほど脱溶剤

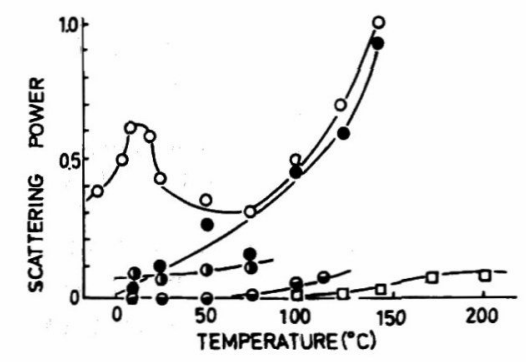

Fig. 5 Small-angle X-ray scattering power of PET treated with organic solvent and silicone oil for 4 hours at various temperatures. Scattering intensity was measured for the PET after removing the solvent.

O-O PET treated with dimethyl formamide.

- PET treated with benzyl alcohol.

- - PET treated with benzene.

- $\odot$ PET treated with tetrachloroethylene.

$\square-\square$ PET treated with silicone oil.

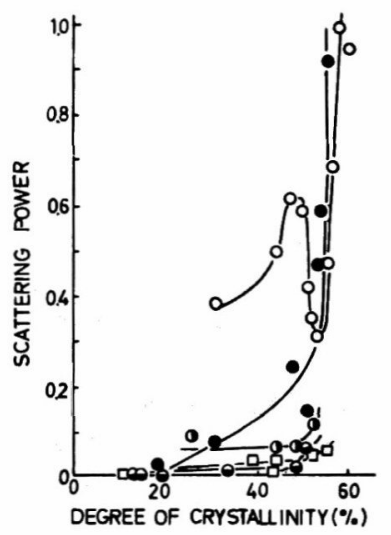

Fig. 6 Small-angle X-ray scattering power of PET plotted against degree of crystallinity.

O-O PET treated with dimethyl formamide.

- PET treated with benzyl alcohol.

- PET treated with benzene.

$\checkmark-\odot$ PET treated with tetrachloroethylene.

$\square-\square$ PET treated with silicone oil.

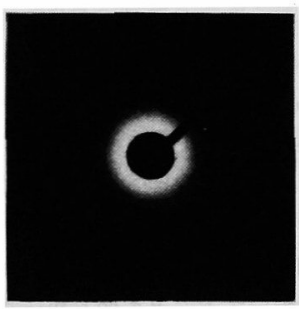

Fig. 7 Small-angle $X$-ray scattering pattern of PET treated with dimethyl formamide at $125^{\circ} \mathrm{C}$.

後多くのボイドが形成されることがわかる。他の溶剤に ついても熱処理温度が高くなるほど散乱能は高くなると いう関係は少なくとも定性的には成立している。

次に, DMF 中で熱処理したPETの散乱能が $10^{\circ} \mathrm{C}$ 以 下で再び低下することについて考察する。DMF， ヘン ジルフルコール中で熱処理したPETの結晶化度が $20 \%$ から $30 \%$ に增大する温度域はそれぞれ異なるが，それら の温度域でペンジルアルコール中で処理した PETの散 乱能は増大寸るが, DMF 中で処理したPETのそれは減 少している。したがって両者の（散乱能一温度）曲線に おける相違を結晶性にもとづいて説明することは困難で ある。したがってDMF 中においては $10^{\circ} \mathrm{C}$ 以下の低温で

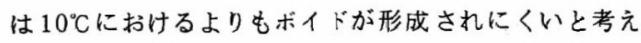
ざるを得ない(それでも他の浴剤中で処理したPETの散 乱能よりは大)。その理由は明確にはわからないが, 次 
のような可能性が考えられる。例えば，七ルロースのク リスタリットやフィブリルの場合も，せルロースと相互作 用の強い水中に分散した状態から乾燥するとそれらは固 着して緻密な組織となるが，セルロースとの相互作用を 持たない容剤(アセトンなど)に分散してから乾燥すると 組織はルーズな状態になる。もし低温においてPETと DMFの間に何らかの相互作用が存在するならば，溶剂 が乾燥過程中に離脱する際P ETの組織はより緻密な状 態になる可能性が考えられる。

\section{(4) 膨潤・乾燥過程の面配向}

フイルム面に対してある結晶軸または結晶面が特定な 配向を示すことがある。例えば，ポリェチレンを金属と の界面において結晶化させると $b$ 軸が金属面に垂直に配 向し、いわゆるトランスクリスタルが形成される。これ は<010>方向における生長が速くフィブリル状の結晶が 形成されるためその立体的要請にもとづいて起こるもの と竸明されている ${ }^{12)}$ 。我々は 6 ナイロンを湿式製膜する と，圧延により(002)面が面配向するのとは異なり， (200)面が面配向することを確かめている ${ }^{18)}$ がこれも 6 ナイロンの微結晶が $a$ 軸方向で生長の速いためであろう と考えている。

一方機械的に压延するとポリビニルアルコールの(101) 面 $^{14), 15)}$ セルロースIIの (101) 面 ${ }^{16)} ， 6$ ナイロンの (020) 面 ${ }^{17)}$, ポリエチレンテレフタレートの $(100)$ 面 ${ }^{18)}$ などが フイルム面に平行に配向することもよく知られている。 このうちポリビニルアルュールの $(101)$ 面 $^{19)}{ }^{21)}$ や ル ロースாの $(101)$ 面22)などは外力を加えなくても，その 製膜過程に面配向することも明らかにされている。この 面配向は，微結晶が(101)表面におけるすべりにより $b$ 軸のまわりに回転することによって起こるといら機構が 高橋 ${ }^{21,28)}$ と松生, 野村, 河合 ${ }^{24)}$ にっって提案されている。 ポリビニルアルコールやセルロース結晶生長はく101> 方向に拈いてはむしろ遅いので，上述のポリエチレンの $b$ 軸, 6 ナイロンの $(200)$ 面の配向の場合と同じ機構に よっては説明できない。

本研究の場合, 低結晶珄・無配向PETをPETと相互 作用の強い有機溶剤に膨潤させた後, 乾燥させたフイル ムにおいて,(100)面がフイルム面に平行に配向する傾向 のあることがわかった。図 8 は原試料のPETフイルム とDMF 中で $-10^{\circ} \mathrm{C}, 20^{\circ} \mathrm{C}, 125^{\circ} \mathrm{C}$ で処理後乾燥した PET フイルムに 2 方向よりX線を入射した時の X 線図である。 $20^{\circ} \mathrm{C}$ で処理した試料においては面配向はほとんど認め られない。しかし，溶媒和のために膨潤時多くの溶剤を 吸収していた低温 $\left(-10^{\circ} \mathrm{C}\right)$ 処理試料においては, 結晶化 度は低いにもかかわらず面配向度はかなり高いことがわ かる。このような面配向は膨潤状態ですでにおこってい

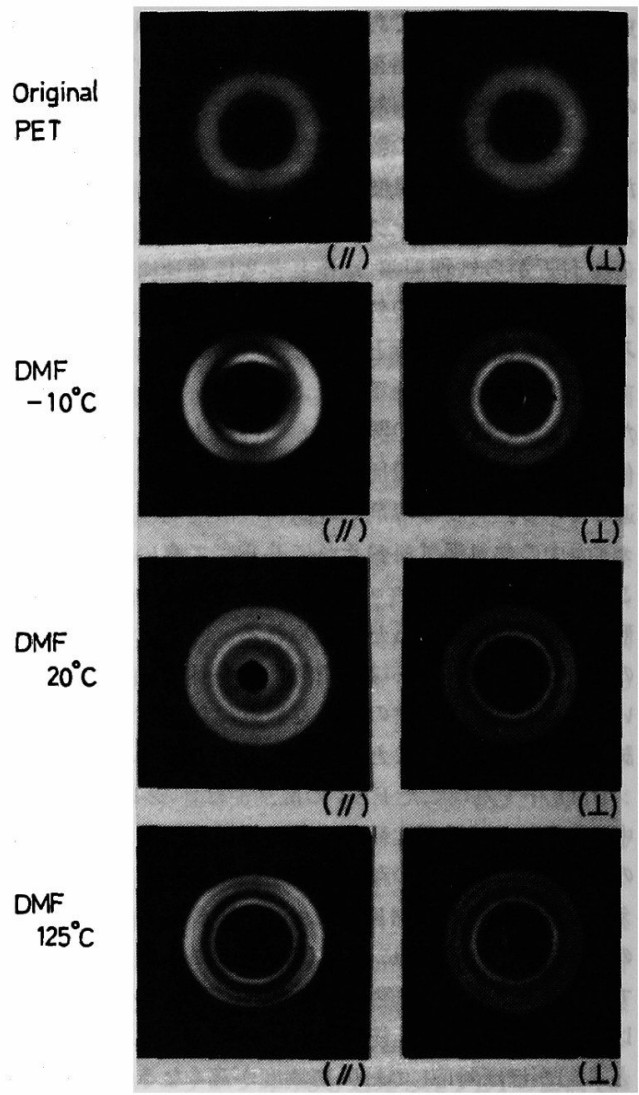

Fig. 8 X-ray diffraction patterns of original PET sample and that of PET treated with dimethyl formamide at $-10^{\circ} \mathrm{C}, 20^{\circ} \mathrm{C}$ and $125^{\circ} \mathrm{C}$.

( II ): X-ray beam parallel to film surface.

$(\perp)$ : X-ray beam perpendicular to film surface.

ることを膨潤状態の X 線図をとることによって確かめた (図 9)。図 9には乾燥を防ぐためにP ETを包んだ Al 馢 にもとづく回折点も認められる。 $125^{\circ} \mathrm{C}$ で処理した試 料においてもわずかに面配向が起こっている。この過程 について考察を試みる。

圧延延伸などの過程を経ている非晶性のPETを熱処 理すると結晶化が起こることによって面配向状態が明確 化されてくるという可能性がまず考えられる。このよう な例は高橋により压延した非晶性のセルロースザンテー 卜金属塩について見出されている ${ }^{22)}$ 。しかし，複屈折を 測定してみてもPETの分子鎖はほとんど無配向状態で あった。また原試料の配向に起因するとすればどのよう 

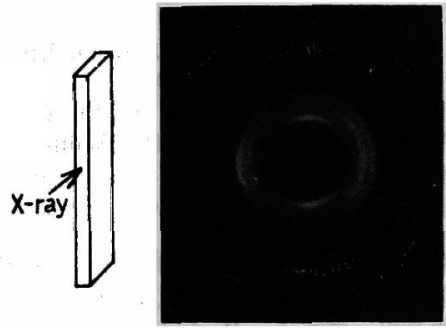

Fig. 9 X-ray diffraction pattern of PET treated with dimethyl formamide at $-10^{\circ} \mathrm{C}$. Swollen PET wrapped with aluminum foil was subjected for X-ray measurement.

X-ray beam parallel to film surface.

な結晶化条件の下でも面配向するはずであるがそうはな らない。この二つの理由により上述の面配向機構は本実 験の結果に適用されない。

次に，PETの結晶の<100>方向はポリェチレンの <010>方向や 6 ナイロンの<100>方向のように結晶生 長が速い方向かということが問題になる。PETの僘結 晶は<100>方向における生長がく010>方向よりも遅れ ていることをBonart ${ }^{26)}$ が指摘しており我々も延伸圧縮し 乾燥処理 $\left(220^{\circ} \mathrm{C}\right)$ したフイルムについてそのことを確か めた。したがってポリエチレンのトランスクリスタル形 成と同様の機構を本実験の結果に適用することも困難で あると考えら扎る。PETの(100)面はむしろ結晶生長 の遅れる面であり，このような結晶面が面配向する ことはポリビニルアルュールやセルロース【の(101)面 の面配向する現象に類似していると我々は考えている。 PETフイルム内部への溶剤の拡散が最外層に形成され た結晶性PETを通じて行われると考えると，この時一 種の唚透圧が生じていると考えてよいであろう。このよ うな物理化学的力に対応して配向する機構として二つの 可能性が考えられる。（1）平板状の分子鎖がフイルム 面に平行に配向し, 引きつづいて起こる結晶化によって 面配向した状態で組織が固定される。(2)(100)面は分 子間力が弱く生長の遅れる面であるから PET の生長初 期に形成される結晶の大きさは $<100>$ 方向で小さく <010>方向で大きいと考えられる(そのような傾向はセ ルロースIにもポリピニルアルコールにも従来認められ ている)。このような平板状の微結晶が物理化学的力に 対応して結晶間の (100)表面におけるすぺりを起こし $c$ 軸のまわりに回転して面配向すると考えられる。どちら にしても(100) 面がフィルム面に平行に配向するので分 子鎖と微結晶のどちらが物理化学的力に対応して動く構 造単位となっているのかは実験的に明らかにできない。
しかし，セルロースIIの面配向過程ではグルコース基を 含む平たい面がむしろフィルム面にほぼ垂直に配列して いるので，今の場合も必ずしも(1)の機構でなければな らない理由はないと考えられる。

\section{4. 結言}

非晶性の未延伸PETフイルムを各種有機溶剤中にお

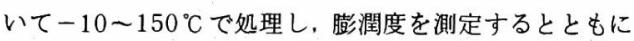
微細構造変化を広角 $\mathrm{X}$ 線回折, 小角 $\mathrm{X}$ 線散乱, そして密 度測定などによって究明した。その結果をまとめると， 次のようになる。

1) ペンジルアルコール, ベンゼン, クロロホルム, アセトニトリル, シクロヘキサン, テトラクロルェチレ ン中で処理したPETの膨潤度は処理温度の上昇ととも に增大した。一方, DMF, DMA，ニトロベンゼン中 で処理したPETの膨潤度は $75^{\circ} \mathrm{C}$ 付近を極小にして温 度が低くても高くても膨潤度が増大した。

2) 各溶闵中で処理した試料の結晶化はシリコンオイ ル中の熱処理試料よりいずれも著しく促進された。結晶 化促進の程度は, PETとの相互作用の強弱に依存して おり, $\mathrm{DMF}>$ ベンゼン>ベンジルアルコール>テトラ クロルェチレンの順に小になる。

3) $\mathrm{DMF}$ 中の $75^{\circ} \mathrm{C}$ 以下の処理試料を除いて, 各溶剂 中で処理した試料は処理温度上昇とともに小角散乱能が 膨潤度变化と対応して増大していることを認めた。特に DMF アベンジルアルコール中の処理試料は顕著にそれ らの値が増大した。

4) 非晶性, 無配向PETをPETと相互作用の強い DMF 中で膨潤させた後乾燥させた試料では，(100)面 がフイルム面に平行に配向することを認めた。この傾向 は $10^{\circ} \mathrm{C}$ 処理試料において特に顕著であった。

付記 : 本研究の一部は昭和 48 年 6 月緎維学会年次大 会(東京)で講演したものである。なお本研究費は財団法 人㵶維工業研究協会の援助によるところ多く，ここに深 謝の意を表する次第である。

\section{文献}

1) 羽賀敏雄, 石橋 博; 繊学誌, 29, T-489 (1972)

2) 万木正, 鈴木 明, 川原俊助, 小田切芙湄子; 岐阜大工学部研究報告, 17, 36 (1967)

3) H.G. Zackman; Faserforsch. u. Textiltech., 18, 427 (1967)

4) W. R. Moore; J. Soc. Dyers Colorists, 73, 500 (1957)

5) J.H. Lemons, S.K. Kaker, D.M. Cates; Am. Dyest. Rep., 55, 76 (1966)

6) R.R. Danbery, C.W. Bunn; Proc. Roy. Soc., A226, 
531 (1954)

7) P.H. Hermans, D. Heikens, A. Weidinger; J. Polymer Sci., 35, 145 (1959)

8) H.F. Mark, N.G. Gaylord, N.M. Bikales; "Encyclopedia of Polymer Science and Technology" vol. 3, P838 (1965), (New York, Interscience Publishers Inc.)

9) 过本在男, 高橋利形, 渡辺孝筧, 藤原久, 水野 恵二，火坂英一郎；载学誌，31，T-226（1975）

10) 辻本石男, 高橋利䫓, 渡辺孝宽, 藤源久, 五十

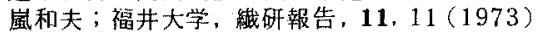

11) P.H. Hermans, A. Weidinger; Makromol. Chem., 18 , 19. 75 (1956)

12) R.K. Eby; J. Appl. Phys., 35, 2720 (1964)

13）高橋利䐜。簡井孝一䬦, 井上朝信; 来発表

14) A. Elliot, E.J. Ambrose, R.B. Temple; Nature, 163,
567 (1949)

15) L. Glatt, D.S. Weffer, C. Seaman, J.W. Ellis; J. Chem. Phys, 18, 413 (1950)

16) W. A. Sisson; J. Phys. Chem., 44, 513 (1940)

17) D.R. Holmens, C.W. Bunn, D.J. Smith; J. Polymer Sci, 17, 159 (1955)

18) W. O. Statton, G. M. Godard; J. Appl. Phys., 28, 1111 (1957)

19) 望月隆吉；日化，80,834 (1959)

20) 望月隆仁；日化，80,1203(1959)

21) 高橋利亚 ; 䋐学誌, 25, 473 (1969)

22) 高橋利頑 ; 繊学誌, 25,80 (1969)

23) 高橋利旗；㵶学誌, 25, 128 (1969)

24) M. Matuo, S. Nomura, H. Kawai; J. Polymer Sci. Polym. Phys. Ed., 11, 2057 (1973)

25) R. Bonart; Kolloid-Z., 213, 1 (1966)

(昭和 51 年 8 月 9 日受理)

\title{
ポリアクリロニトリル無配向フィルムの無定形領域 の微細構造と染色性の相関性*
}

\author{
旭化成工業株式会社瀻維加工研究所 中山暢三** 上出健二** 真鍋征一** \\ CORRELATION BETWEEN FINE STRUCTURE OF AMORPHOUS REGION \\ AND DYEABILITY OF POLYACRYLONITRILE UNORIENTED FILM
}

By Chozo Nakayama, Kenii Kamide, and Sei-ichi Manabe

(Textile Research Laboratory, Asahi Chemical Industry Company Ltd., Hacchonawate, Takatsuki city, Osaka, Japan)

\begin{abstract}
Fine structure of amorphous region of polyacrylonitrile (PAN) unoriented film was evaluated according to the method proposed by Manabe, Kamide and Nakayama from dynamic loss tangent $(\tan \delta)$ - temperature curve. Correlationships between the fine structures thus determined and dyeability of this film by disperse and basic dyes were examined in detail. For this purpose, two disperse dyes (molecular weight, 242 and 480) with the ratio of inorganic value/organic value of ca. 0.65 , which was a parameter for representing the polarity of dye, and two basic dyes (molecular weight, 408 and 480 ) with the ratio of inorganic value/organic value of ca. 0.50 were employed. As sample films for dyeing were prepared by casting a solution of PAN in $N, N^{\prime}$-dimethylformamide and by annealing the virgin PAN film at $100{ }^{\circ} \mathrm{C}$ in vapor steam for various periods of time $(\sim 60 \mathrm{~min}$.). Molecules of disperse dyes diffused mainly into region 2, where PAN molecules in amorphous region aggregated in loosely-packed state. The exhausted dye concentration expressed by optical density was in linear proportion to elastic modulus fraction corresponding a given value of heterogeneity index $n_{u}{ }^{\circ}$ or less. The value of $n_{u^{\circ}}$ increased with decrease in the molecular weight of disperse dye and with increase in dyeing time. In other words, the dye molecules diffused into the rather densely packed region of the region 2 with increasing lapse of dyeing time.
\end{abstract}

(Received August 9, 1976)

*この報文を「ポリアクリロニトリルの無定形領域における微細構造の研究(第3 報)， Studies on the Fine Structure] of Amorphous Region of Polyacrylonitrile (Part 3)」とする。

** 旭化成工業(株)㵶維加工研究所, 大阪府高梘市八丁畷町 110 7, Textile Research Laboratory, Asahi Chemical Industry Company Ltd., Hacchonawate 11-7, Takatsuki city, Osaka, Japan 